\title{
ISOTOPIC POWER FUELS MONTHLY STATUS REPORT FOR OCTOBER 1972
}

\author{
Eugene Lamb
}

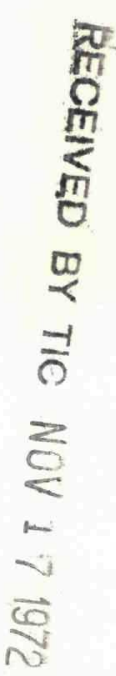

\section{OAK RIDGE NATIONAL LABORATORY}




\section{DISCLAIMER}

This report was prepared as an account of work sponsored by an agency of the United States Government. Neither the United States Government nor any agency Thereof, nor any of their employees, makes any warranty, express or implied, or assumes any legal liability or responsibility for the accuracy, completeness, or usefulness of any information, apparatus, product, or process disclosed, or represents that its use would not infringe privately owned rights. Reference herein to any specific commercial product, process, or service by trade name, trademark, manufacturer, or otherwise does not necessarily constitute or imply its endorsement, recommendation, or favoring by the United States Government or any agency thereof. The views and opinions of authors expressed herein do not necessarily state or reflect those of the United States Government or any agency thereof. 


\section{DISCLAIMER}

Portions of this document may be illegible in electronic image products. Images are produced from the best available original document. 
This report was prepared as an account of work sponsored by the United States Government. Neither the United States nor the United States Atomic Energy Commission, nor any of their employees, nor any of their contractors, subcontractors, or their employees, makes any warranty, express or implied, or assumes any legal liability or responsibility for the accuracy, completeness or usefulness of any information, apparatus, product or process disclosed, or represents that its use would not infringe privately owned rights. 
Contract No. W-7405-eng-26

ISOTOPES DEVELOPMENT CENTER

ISOTOPIC POWER FUELS MONTHLY

STATUS REPORT FOR OCTOBER 1972

Eugene Lamb

Isotopes Division

NOTICE

This report was prepared as an account of work sponsored by the United States Government. Neither the United States nor the United States Atomic Energy Commission, nor any of their employees, nor any of their contractors, subcontractors, or their employees, makes any warranty, express or implied, or assumes any legal liability or responsibility for the accuracy, completeness or usefulness of any information, apparatus, product or process disclosed, or represents that its use would not infringe privately owned rights.

NOTICE This document contains information of a preliminary nature and was prepared primarily for internal use at the Oak Ridge National Laboratory. It is subject to revision or correction and therefore does not represent a final report.

OAK RIDGE NATIONAL LABORATORY

Oak Ridge, Tennessee 37830

operated by

UNION CARBIDE CORPORATION

for the

U.S. ATOMIC ENERGY COMMISSION 


\section{CONTENTS}

CURIUM-244 FUEL DEVELOPMENT . . . . . . . . . . . . . . . . 1

Curium Oxide Fuel Development and Properties ........ . 1 ${ }^{244} \mathrm{Cm}_{2} \mathrm{O}_{3}$ Compatibility Program ............. 1

Vapor Transport of ${ }^{244} \mathrm{Cm}_{2} \mathrm{O}_{3}$............... 2 APPENDIX, Curium-244 Inventory . . . . . . . . . . . . . 2 


\title{
CURIUM-244 FUEL DEVELOPMIENT
}

\author{
(Division of Space Nuclear Systems Program 043005 03)
}

Curium Oxide Fuel Development and Properties

${ }^{244} \mathrm{Cm}_{2} \mathrm{O}_{3}$ Compatibility Program

Procurement of materials and other test-system components is continuing. Precious-metal melting stock was obtained for all metals and alloys except those involving iridium, and machining of test components is now under way.

The two ceramic materials selected for inclusion in this program are $\mathrm{ThO}_{2}$ and $\mathrm{ZrO}_{2}$. Rods of $\mathrm{ThO}_{2}$ were prepared and are being machined into modified inner-capsule test-system components. An order has recently been placed to commercially obtain $\mathrm{ZrO}_{2}$ inner-capsule components. We expect that procurement of a11 test-system components, except those involving iridium, will be completed by December 15, 1972 .

A short-term compatibility experiment was performed between $\mathrm{SiC}$ and $\mathrm{CmO}_{2}$. The objective of the test was to determine if SiC could be used in our compatibility matrix as a high-temperature containment form for $\mathrm{Cm}_{2} \mathrm{O}_{3}$. Curium dioxide and SiC were weighed out to mole ratios of $1: 2$, respectively. The powders were mixed by mortar and pestle and then coldpressed into a pellet. The pellet was loaded into a tungsten crucible, which was put into a high-temperature vacuum furnace. The pellet was observed as temperature of the furnace was slowly increased. A noticeable increase in gas pressure occurred above $1200^{\circ} \mathrm{C}$; at $1560^{\circ} \mathrm{C}$, the pellet appeared to be melting. After the pellet was removed from the furnace, it was observed that approximately one-half had melted. The mass fraction lost by the crucible and pellet was 0.345 . The melted substance appeared to have a shiny, silvery metallic luster. Part of the unmelted substance was submitted for $\mathrm{x}$-ray diffraction analysis.

Two of the possible reactions which could have occurred are:

$$
\begin{aligned}
& \mathrm{CmO}_{2}+2 \mathrm{SiC} \rightarrow \mathrm{CmC}_{2}+2 \mathrm{SiO} \uparrow \\
& \mathrm{CmO}_{2}+2 \mathrm{SiC} \rightarrow \mathrm{CmSi}_{2}+2 \mathrm{CO} \uparrow
\end{aligned}
$$

The mass fractions lost in reactions (1) and (2) are 0.247 and 0.157 , respectively. In the present case more mass was lost than either of the two above reactions could account for. Part of the sample had either volatilized or escaped the crucible. From the increase in gas 
pressure and from the melting point of the product, it appears as if a curium silicide product was formed. The $x$-ray diffraction analysis, which has not been received, should identify the product. This experiment clearly showed that the material SiC should not be used for containment of $\mathrm{Cm}_{2} \mathrm{O}_{3}$ at high temperatures.

An examination of the $\mathrm{BeO}-{ }^{244} \mathrm{Cm}_{2} \mathrm{O}_{3}$ system showed the formation of lowmelting eutectics $\left(\sim 1650^{\circ} \mathrm{C}\right)$, which was cause for elimination of $\mathrm{BeO}$ ceramic from the test matrix. ${ }^{1}$

Vapor Transport of $244 \mathrm{Cm}_{2} \mathrm{O}_{3}$

Mass spectra have been obtained with the mass spectrometer unit. A calibrated gas mixture has been prepared and used to tune the system. We are presently testing the unit with $\mathrm{Nd}_{2} \mathrm{O}_{3}$ to determine the lowest temperature at which NdO or Nd is first observed. Neodymium oxide is being used as a stand-in for ${ }^{244} \mathrm{Cm}_{2} \mathrm{O}_{3}$ because it has been previously studied and probably has a vapor pressure similar to $\mathrm{Cm}_{2} \mathrm{O}_{3}$. The NdO and INd peaks have been observed at $1650^{\circ} \mathrm{C}$.

\section{APPENDIX}

Curium-244 Inventory

Cumulative Receipts and Usage

Cumulative Receipts from SRL

Allocated to 04 Heat Source Program

Current Use in ORNL Test Program

Analytical Samples from Test Program

Shipped to Lovelace Foundation

Shipped to SRL for Analysis

Test Program Residues for Recycle

Discarded to ORNL Tank Farm

Raw Material Inventory, 04 Heat Source Program
4-30-72

Allocated to 05 Transuranium Program

Transferred to TRU

Shipments to Other Sites

Transferred to Target Fabrication Group

2488

2148

(379)

(6)

haw Material Inventory, 05 Transuranium Program

Total Raw Material Inventory on October 31, 1972

1667

1544

340

$199 \quad \underline{184}$

$1866 \quad 1728$

\footnotetext{
${ }^{1}$ Eugene Lamb, Isotopic Power Fuels Monthly Status Report for August 1972, ORNL-TM-3982, Oak Ridge National Laboratory.
} 
INTERNAL DISTRIBUTION

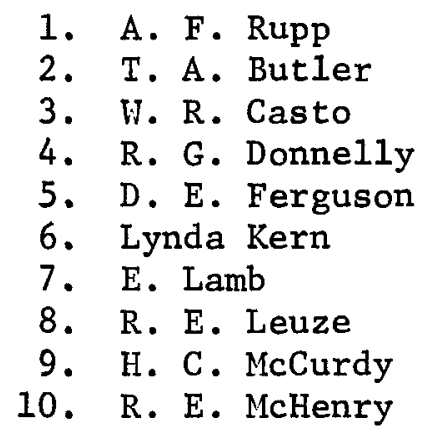

$$
\begin{aligned}
& \text { 11. } \text { M. E. Ramsey } \\
& \text { 12-13. } \text { R. A. Robinson } \\
& \text { 14. } \text { A. H. Snell } \\
& \text { 15. R. W. Schaich } \\
& \text { 16. } \text { D. B. Trauger } \\
& \text { 17. } \text { Laboratory Records - RC } \\
& \text { 18-20. Laboratory Records Department } \\
& \text { 21-23. } \text { Central Research Library } \\
& \text { 24. Document Reference Section } \\
& \text { 25. }
\end{aligned}
$$

\section{EXTERNAL DISTRIBUTION}

26-27. R. D. Baker, Los Alamos Scientific Laboratory

28. W. Brooksbank, G. C. Marshall Space Flight Center, NASA

29. R. T. Carpenter, AEC-SNS, Washington, D.C.

30. W. T. Cave, Mound Laboratory

31. J. Coleman, Nuclear Utilities Services Corporation

32. G. R. Crane, Andrews Air Force Base

33. D. D. Davis, Dayton Area Office, AEC

34. G. P. Dix, AEC-SNS, Washington, D.C.

35. H. C. Donnelly, Albuquerque Area Office, AEC

36. J. Epstein, Goddard Space Flight Center, NASA

37. R. K. Flitcraft, Monsanto Research Corporation

38-39. E. E. Fowler, AEC-DAT, Washington, D.C.

40. L. Frank, Weiner Associates, Inc.

41. D. S. Gabrie1, AEC-SNS, Washington, D.C.

42. N. Goldenberg, AEC-SNS, Washington, D.C.

43. A. Hoffman, TRW Systems

44. R. G. Ivanoff, Jet Propulsion Laboratory

45. H. Jaffe, AEC-SNS, Washington, D.C.

46. J. H. Jarrett, Pacific Northwest Laboratory

47. E. Katzen, Ames Research Center

48. T. B. Kerr, NASA Headquarters

49. F. E. Kruesi, Savannah River Laboratory

50. G. Linkous, Isotopes, Inc.

51. S. V. Manson, NASA Headquarters

52. T. A. Nemzek, AEC-ROO

53. G. A. Newby, AEC-SNS, Washington, D.C.

54. W. Pardue, Battelle Memorial Institute

55. J. A. Powers, AEC-SNS, Washington, D.C.

56. T. E. Redding, NASA

57. W. Remini, NASA

58. C. R. Richmond, AEC-BM, Washington, D.C.

59. R. Schafer, General Electric Company

60. E. H. Schneider, AEC-SNS, Washington, D.C.

61. F. Schulman, AEC-SNS, Washington, D.C.

62. M. Shaw, AEC-RDT, Washington, D.C.

63. H. C. Slone, Lewis Research Center

64. M. D. Starr, Naval Facilities Engineering Command 
65. N. Stetson, AEC-SROO

66. V. Truscello, Jet Propulsion Laboratory

67. D. Watrous, Donald W. Douglas Laboratories

68. A. Wilber, Ames Research Center

69. H. H. Youngblood, Langley Research Center

70. Research and Technical Support Division, AEC-ORO

71-72. Technical Information Center 